\title{
Sphingopyxis ummariensis sp. nov., isolated from a hexachlorocyclohexane dump site
}

Correspondence

Rup Lal

duzdel@vsnl.com

\author{
Pooja Sharma,† Mansi Verma,† Kiran Bala, Aeshna Nigam and Rup Lal \\ Department of Zoology, University of Delhi, Delhi - 110 007, India
}

\begin{abstract}
A Gram-negative, motile, rod-shaped, yellow-pigmented bacterium, strain $\mathrm{UI} 2^{\top}$, was isolated from a hexachlorocyclohexane $(\mathrm{HCH})$ dump site located in Ummari, in northern India. 16S rRNA gene sequence analysis revealed that strain $\mathrm{UI} 2^{\top}$ belongs to the genus Sphingopyxis and showed highest 16S rRNA gene sequence similarity with Sphingopyxis terrae IFO $15098^{\top}(98.6 \%)$. DNA-DNA relatedness values between strain UI2 ${ }^{\top}$ and Sphingopyxis terrae IFO $15098^{\top}$ and other related strains were found to be less than $46 \%$. The major cellular fatty acids of strain UI2 were $\mathrm{C}_{18: 1} \omega 7 c(28.3 \%), \mathrm{C}_{16: 0}(14.4 \%), 11$-methyl $\mathrm{C}_{18: 1} \omega 7 c(10.9 \%), \mathrm{C}_{17: 1} \omega 6 c(9.6 \%)$ and summed feature 3 (consisting of $\mathrm{C}_{16: 1} \omega 7 \mathrm{c}$ and/or $\mathrm{C}_{15: 0}$ iso $2-\mathrm{OH} ; 14.7 \%$ ). The DNA G+C content of strain $\mathrm{UI} 2^{\top}$ was $68 \mathrm{~mol} \%$. On the basis of DNA-DNA hybridization, phenotypic characteristics and phylogenetic analysis, strain $\mathrm{UI}^{\top}{ }^{\top}$ is found to represent a novel species of the genus Sphingopyxis, for which the name Sphingopyxis ummariensis sp. nov. is proposed. The type strain is $\mathrm{UI} 2^{\top}\left(=\right.$ CCM $7428^{\top}=$ MTCC $\left.8591^{\top}\right)$.
\end{abstract}

The genus Sphingopyxis was introduced after the subdivision of the genus Sphingomonas by Takeuchi et al. (2001) and is currently represented by 12 species: Sphingopyxis terrae (Takeuchi et al., 1993, 2001), S. macrogoltabida (Takeuchi et al., 1993, 2001), S. alaskensis (Vancanneyt et al., 2001; Godoy et al., 2003), S. taejonensis (Lee et al., 2001; Pal et al., 2006), S. witflariensis (Kämpfer et al., 2002), S. chilensis (Godoy et al., 2003), S. flavimaris (Yoon \& Oh, 2005), S. baekryungensis (Yoon et al., 2005), 'S. granuli' (Kim et al., 2005; this name has not been validly published), S. ginsengisoli (Lee et al., 2008), S. marina (Kim et al., 2008) and S. litoris (Kim et al., 2008).

A yellow-coloured strain, designated $\mathrm{UI} 2^{\mathrm{T}}$, was isolated from a hexachlorocyclohexane $(\mathrm{HCH})$ dump site at Ummari village in northern India. For this purpose, an $\mathrm{HCH}$-contaminated soil sample was serially diluted and plated on nystatin- and streptomycin-amended LuriaBertani (LB) agar plates (Vanbroekhoven et al., 2004; Dadhwal et al., 2009). A yellow-coloured colony that appeared within $36 \mathrm{~h}$ of incubation at $28^{\circ} \mathrm{C}$ was picked and purified by repeated streaking on LB agar. Strain UI $2^{\mathrm{T}}$

†These authors contributed equally to this work.

Abbreviation: $\mathrm{HCH}$, hexachlorocyclohexane.

The GenBank/EMBL/DDBJ accession number for the 16S rRNA gene sequence of strain UI2 ${ }^{\top}$ is EF424391.

An EM of a cell of strain UI2 ${ }^{\top}$, results of TLC analysis of its polar lipids and tables of DNA-DNA relatedness values and fatty acid compositions are available as supplementary material with the online version of this paper. was characterized taxonomically by using a polyphasic approach (Prakash et al., 2007b).

Colonies were yellow and circular with entire margins and varied in size from 0.5 to $2 \mathrm{~mm}$ within 2 days of incubation. Colony morphology was studied on LB agar, nutrient agar (NA) and tryptic soya agar (TSA). Strain $\mathrm{UI} 2^{\mathrm{T}}$ grew well under aerobic conditions on LB agar, NA and TSA at $28{ }^{\circ} \mathrm{C}$ within $24-48 \mathrm{~h}$ of incubation. Gramstaining was performed using a Gram-stain kit (HiMedia) and strain UI2 ${ }^{\mathrm{T}}$ was found to stain Gram-negative. After preparing cells as described by Kumar et al. (2008), a subpolar (monotrichous) flagellum was observed by transmission electron microscope (Supplementary Fig. S1, available in IJSEM Online). Motility of the organism was also checked on motility agar (Farmer, 1999).

The 16S rRNA gene sequence of the strain $\mathrm{UI} 2^{\mathrm{T}}$ was amplified by colony PCR using the universal primers $27 \mathrm{~F}$ and $1492 \mathrm{R}$ and sequenced as described by Kumar et al. (2008) and Jit et al. (2008). A continuous stretch of $1408 \mathrm{bp}$ of the $16 \mathrm{~S}$ rRNA gene sequence obtained was subjected to similarity searches by using the sequence matching tool of Ribosomal Database Project II (http:// rdp.cme.msu.edu/) and the NCBI BLAST program (http:// blast.ncbi.nlm.nih.gov/Blast.cgi). The nearly full-length $16 \mathrm{~S}$ rRNA gene sequences of strains closely related to UI $2^{\mathrm{T}}$ were retrieved for the construction of a phylogenetic tree. The selected sequences were aligned using CLUSTAL $\mathrm{X}$ version 1.81b (Thompson et al., 1997). The evolutionary distance matrix was calculated using the distance model of Jukes \& Cantor (1969) within TREECON version 1.3b (Van de Peer \& 
De Wachter, 1994) using a 1330 bp alignment and the resultant tree topology was evaluated using bootstrap analysis of 1000 resamplings. A phylogenetic tree was constructed using the neighbour-joining method of Saitou \& Nei (1987). Evaluation of the tree topology revealed that strain UI2 ${ }^{\mathrm{T}}$ clustered with members of the genus Sphingopyxis and formed a monophyletic clade with $S$. terrae IFO $15098^{\mathrm{T}}$ (Fig. 1). A similar tree topology was also observed using neighbour-joining and maximum-parsimony methods with PHYLIP version 3.5 (Felsenstein, 1993).

$16 \mathrm{~S}$ rRNA gene sequence similarity values between strain $\mathrm{UI}^{\mathrm{T}}$ and Sphingopyxis strains ranged from 93.6 to $98.6 \%$, with the highest similarity to S. terrae IFO $15098^{\mathrm{T}}$ (98.6\%), followed by S. witflariensis $\mathrm{W}-50^{\mathrm{T}}(97.9 \%)$, 'S. granuli' Kw07 (97.9\%), S. ginsengisoli Gsoil $250^{\mathrm{T}}(97.9 \%)$, S. taejonensis JSS54 ${ }^{\mathrm{T}}(97.4 \%)$, S. alaskensis RB2256 ${ }^{\mathrm{T}}(97.3 \%)$, S. chilensis $\mathrm{S}^{\mathrm{T}}{ }^{\mathrm{T}}(97.2 \%)$, S. macrogoltabida IFO $15033^{\mathrm{T}}$ $(97.1 \%)$, S. flavimaris $\mathrm{SW}-151^{\mathrm{T}}(95 \%)$, S. baekryungensis SW- $150^{\mathrm{T}}(94.4 \%)$, S. marina $\mathrm{FR} 1087^{\mathrm{T}}(94.4 \%)$ and $S$. litoris $\mathrm{FR} 1093^{\mathrm{T}}(93.6 \%)$.

DNA-DNA hybridizations between strain UI2 ${ }^{\mathrm{T}}$ and strains of Sphingopyxis species with 16S rRNA gene sequence similarity values greater than $97 \%$ were carried out by the membrane-filter method (Tourova \& Antonov, 1988; Prakash et al., 2007a; Kumar et al., 2008). S. terrae DSM $8831^{\mathrm{T}}$, S. witflariensis DSM $14551^{\mathrm{T}}$, S. taejonensis DSM $15583^{\mathrm{T}}$, S. alaskensis DSM $13593^{\mathrm{T}}$, S. chilensis DSM $14889^{\mathrm{T}}$ and S. macrogoltabida DSM $8826^{\mathrm{T}}$ were obtained from the Deutsche Sammlung von Mikroorganismen und Zellkulturen, Braunschweig, Germany. 'S. granuli' KCTC 12209 and S. ginsengisoli KCTC $12582^{\mathrm{T}}$ were obtained from Korean Collection for Type Cultures, Seoul, Korea. Strain
$\mathrm{UI} 2^{\mathrm{T}}$ was most closely related to $S$. terrae DSM $8831^{\mathrm{T}}$ (DNA-DNA relatedness value $42.2 \%$; Supplementary Table S1). Hybridization values of strain UI2 ${ }^{\mathrm{T}}$ with other strains of the genus Sphingopyxis were less than $46 \%$. Since all hybridization values were below $70 \%$, as is recommended for the delineation of species (Wayne et al., 1987; Stackebrandt \& Goebel, 1994), this confirms that strain $\mathrm{UI} 2^{\mathrm{T}}$ represents a novel species of the genus Sphingopyxis.

Fatty acid methyl ester analysis was performed as described by Prakash et al. (2007a). The polar lipid profile of strain $\mathrm{UI} 2^{\mathrm{T}}$ was generated by two-dimensional TLC as described by Gupta et al. (2009). Aqueous premulin (1\%) solution was used for detection of lipids under UV light. Polyamines were extracted as described by Busse \& Auling (1988) and analysed by TLC (silica gel $60 \mathrm{~F}_{254} 20 \times 20 \mathrm{~cm}, 1.05554 .0007$; Merck) at IMTECH (Chandigarh, India). Quinones were extracted from $200 \mathrm{mg}$ dry cell mass with a $10 \%$ aqueous solution of $0.3 \%(\mathrm{w} / \mathrm{v}) \mathrm{NaCl}$ in methanol and petroleum ether (boiling point $60-80{ }^{\circ} \mathrm{C}$ ) at a ratio of $1: 1(\mathrm{v} / \mathrm{v})$. The upper phase was collected and dried in a Buchi Rotavapor and the residue was dissolved in $100 \mu \mathrm{l}$ acetone. The extract was analysed by TLC, as above using petroleum ether and diethyl ether at a ratio of $85: 15(\mathrm{v} / \mathrm{v})$. Purified ubiquinones were dissolved in 2-propanol and analysed by reversedphase TLC according to Collins \& Jones (1980).

The predominant fatty acids of strain UI2 ${ }^{\mathrm{T}}$ were $\mathrm{C}_{18: 1} \omega 7 c$ $(28.3 \%), \mathrm{C}_{16: 0}(14.4 \%)$, 11-methyl $\mathrm{C}_{18: 1} \omega 7 c(10.9 \%)$, $\mathrm{C}_{17: 1} \omega 6 c(9.6 \%)$ and summed feature 3 (consisting of $\mathrm{C}_{16: 1} \omega 7 c$ and/or $\mathrm{C}_{15: 0}$ iso 2-OH; $14.7 \%$ ) (Supplementary Table S2). $\mathrm{C}_{16: 1} \omega 5 c(3.3 \%)$ and $\mathrm{C}_{18: 0}(2.4 \%)$ were also detected, along with three characteristic hydroxylated fatty acids, $\mathrm{C}_{14: 0} 2-\mathrm{OH}(6.1 \%), \mathrm{C}_{15: 0} 2-\mathrm{OH}(4.1 \%)$ and $\mathrm{C}_{16: 0}$

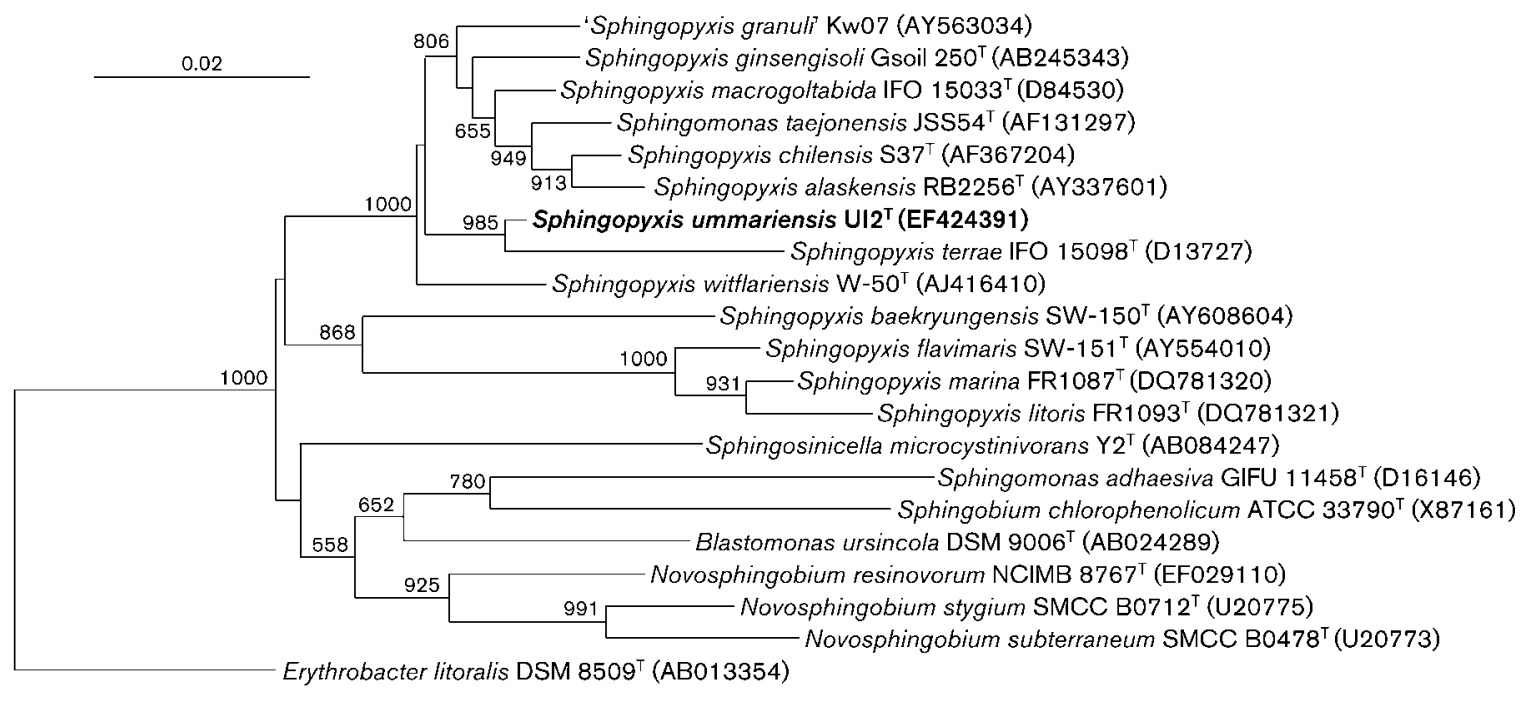

Fig. 1. Neighbour-joining phylogenetic tree based on nearly complete $16 \mathrm{~S}$ rRNA gene sequences showing the relationship of strain UI2 ${ }^{\top}$ and members of related genera. The sequence of Erythrobacter litoralis DSM $8509^{\top}$ was used as an outgroup. Bootstrap values $(>500)$ based on 1000 resamplings are shown at branch nodes. Bar, 0.02 substitutions per nucleotide position. 
2-OH (3.2\%). In addition, $\mathrm{C}_{19: 0}$ cyclo $\omega 8 c(3.2 \%)$, which has not been reported earlier in the genus Sphingopyxis, was also detected in strain UI2 ${ }^{\mathrm{T}}$. Fatty acid analysis confirmed the inclusion of strain UI2 ${ }^{\mathrm{T}}$ in the genus Sphingopyxis. The polar lipid analysis of strain $\mathrm{UI} 2^{\mathrm{T}}$ exhibited the presence of phosphatidylethanolamine, diphosphatidylglycerol, phosphatidylglycerol, phosphatidylcholine, phosphatidylmonomethylethanolamine, sphingoglycolipids and traces of unidentified glycolipids and lipids (Supplementary Fig. S2). These are the common polar lipids reported for sphingomonads (Busse et al., 1997). Strain UI2 ${ }^{\mathrm{T}}$ contained both spermidine and spermine, and spermidine was identified as the major polyamine. Strain UI $2^{\mathrm{T}}$ contained ubiquinone Q-10 as the major respiratory quinone. The

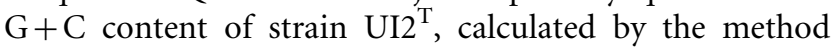
described by Gonzalez \& Saiz-Jimenez (2002) and the Applied Biosystems 7500 Real-Time PCR system, was found to be $68 \mathrm{~mol} \%$.

The results of the chemotaxonomic analyses are given in the species description and Table 1 . Growth at 4, 10,20, 28, 33, 37 and $43{ }^{\circ} \mathrm{C}$, at $\mathrm{pH} 4-9$ (in increments of one $\mathrm{pH}$ unit) and with $0,1,3,5$ and $7 \%(\mathrm{w} / \mathrm{v}) \mathrm{NaCl}$ was tested in LB as described by Arden Jones et al. (1979). All biochemical tests were carried out at $28{ }^{\circ} \mathrm{C}$. Acid production from carbohydrates and assimilation of substrates on mineral medium were determined as described by Gordon et al. (1974). Production of indole and hydrolysis of casein, gelatin, starch and aesculin were tested as described by Cowan \& Steel (1965). Degradation of $\alpha$-, $\beta$-, $\gamma$ - and $\delta$-isomers of $\mathrm{HCH}$ was investigated as described by Kumari et al. (2002). Nitrate reduction was tested as described by Prakash et al. (2007a). Catalase production was tested with $3 \%(\mathrm{v} / \mathrm{v})$ hydrogen peroxide solution as described by McCarthy \& Cross (1984). Oxidase production was tested using bacteriological differentiation discs. Urease activity was tested according to Christensen (1946). Hydrolysis of Tween 20 was tested according to Arden Jones et al. (1979). Degradation of hypoxanthine and xanthine was tested according to Gordon et al. (1974). $\beta$-Galactosidase activity was observed using ONPG discs. Susceptibility towards antibiotics was determined on Mueller-Hinton agar using ready-made discs as follows ( $\mu \mathrm{g}$ per disc): ampicillin (10), chloramphenicol (30), chlortetracycline (30), erythromycin (15), gentamicin (10), kanamycin (30), neomycin (30), novobiocin (30), oxytetracycline (30), penicillin G (10), rifampicin (5), tetracycline (30) and vancomycin (30).

On the basis of the phenotypic, chemotaxonomic and phylogenetic analysis, it is proposed that strain $\mathrm{UI}^{\mathrm{T}}$ represents a novel species, for which the name Sphingopyxis ummariensis sp. nov. is proposed.

\section{Description of Sphingopyxis ummariensis sp. nov.}

Sphingopyxis ummariensis (um.ma.ri.en'sis. N.L. fem. n. ummariensis pertaining to Ummari village, the place of isolation of the type strain).
Table 1. Differential morphological and physiological characteristics of strain $\mathrm{UI} 2^{\top}$ and other members of genus Sphingopyxis

Strains: 1, Sphingopyxis ummariensis sp. nov. UI2 ${ }^{\mathrm{T}}$; 2 , S. terrae DSM $8831^{\mathrm{T}}$; 3, S. witflariensis DSM $14551^{\mathrm{T}} ; 4$, S. taejonensis DSM $15583^{\mathrm{T}} ; 5$, S. alaskensis DSM $13593^{\mathrm{T}} ; 6$, S. chilensis DSM $14889^{\mathrm{T}} ; 7, S$. macrogoltabida DSM $8826^{\mathrm{T}} ; 8$, S. ginsengisoli KCTC $12582^{\mathrm{T}}$; 9, 'S. granuli KCTC 12209. Data were taken from this study. All strains were Gram-negative, rod-shaped, motile, positive for catalase, oxidase and Tween 20 hydrolysis and negative for utilization of citrate and adonitol, hydrolysis of casein, hypoxanthine, xanthine and starch, indole production and nitrate reduction. + , Positive; $(+)$, weakly positive; $\mathrm{v}$, variable reaction in triplicate samples; - , negative; $\mathrm{ND}$, not determined.

\begin{tabular}{|lccccccccc|}
\hline Characteristic & $\mathbf{1}$ & $\mathbf{2}$ & $\mathbf{3}$ & $\mathbf{4}$ & $\mathbf{5}$ & $\mathbf{6}$ & $\mathbf{7}$ & $\mathbf{8}$ & $\mathbf{9}$ \\
\hline Colony & Y & LY/DY & Y & PY & Y-BG & Y & WHB/Y & Y-BG & WH \\
colour & & & & & & & & & \\
Assimilation & & & & & & & & & \\
of: & & & & & & & & & \\
L-Arabinose & + & - & - & - & - & - & + & - & - \\
Fructose & + & - & - & + & - & + & - & - & - \\
Lactose & $(+)$ & - & $(+)$ & - & - & - & + & - & - \\
D-Mannitol & - & + & - & - & - & - & $(+)$ & - & - \\
D-Ribose & + & + & - & - & - & - & ND & - & - \\
Sorbitol & $(+)$ & + & - & - & - & + & $(+)$ & - & - \\
Xylose & + & - & - & + & - & $(+)$ & - & - & - \\
Hydrolysis of: & & & & & & & & & \\
Aesculin & + & $\mathrm{V}$ & - & - & + & + & $(+)$ & + & + \\
Gelatin & - & - & - & - & - & - & $\mathrm{V}$ & - & - \\
Urea & - & - & - & - & $\mathrm{V}$ & - & - & - & - \\
$\beta$-Galacto- & - & - & - & + & + & $(+)$ & + & - & - \\
sidase & & & & & & & & & \\
Citrate & - & - & - & - & - & - & - & - & + \\
utilization & & & & & & & & & \\
\hline
\end{tabular}

${ }^{{ }_{B}}$, Beige; DY, deep yellow; LY, light yellow; PY, pale yellow; WH, white; wHB, whitish brown; Y, yellow.

Gram-negative, motile, aerobic, rod-shaped bacterium. Subpolar flagellum present. Cell size $0.8 \times 0.1 \mu \mathrm{m}$. Colonies are yellow and circular with entire margins, $1.2-2 \mathrm{~mm}$ in diameter after $72 \mathrm{~h}$ of incubation on LB agar. Optimum conditions for growth are $28{ }^{\circ} \mathrm{C}$, pH 7.5 and $1 \% \mathrm{NaCl}$. Does not degrade $\alpha-, \beta-, \gamma$ - or $\delta$-isomers of HCH $\left(5 \mu \mathrm{g} \mathrm{ml}{ }^{-1}\right)$. Nitrate is not reduced to nitrite or nitrogen. Catalase- and oxidase-positive. Indole production is negative. No $\beta$ galactosidase activity detected. Hydrolyses aesculin and Tween 20, but does not hydrolyse gelatin, starch, casein, urea, hypoxanthine or xanthine. Acid is produced from trehalose, D-glucose and D-ribose. Assimilates cellobiose, maltose, D-mannose, D-ribose, fructose, D-glucose, Larabinose, xylose and trehalose; assimilates galactose, lactose and sorbitol weakly. Sensitive to chloramphenicol, chlortetracycline, erythromycin, gentamicin, kanamycin, neomycin, novobiocin, oxytetracycline, penicillin G, rifampicin, tetracycline and vancomycin; less sensitive to 
ampicillin. Major polar lipids are phosphatidylethanolamine, diphosphatidylglycerol, phosphatidylglycerol, phosphatidylcholine and sphingoglycolipid. The fatty acids $\mathrm{C}_{18: 1} \omega 7 c, \mathrm{C}_{16: 0}, 11$-methyl $\mathrm{C}_{18: 1} \omega 7 c, \mathrm{C}_{17: 1} \omega 6 c, \mathrm{C}_{19: 0}$ cyclo $\omega 8 c$ and summed feature $3\left(\mathrm{C}_{16: 1} \omega 7 c 2-\mathrm{OH}\right.$ and/or $\mathrm{C}_{15: 0}$ iso 2- $\mathrm{OH})$ are detected in addition to $\mathrm{C}_{14: 0} 2-\mathrm{OH}, \mathrm{C}_{15: 0} 2-\mathrm{OH}$, $\mathrm{C}_{16: 0} 2-\mathrm{OH}, \mathrm{C}_{16: 1} \omega 5 c$ and $\mathrm{C}_{18: 0}$. Ubiquinone Q-10 is the major respiratory quinone. The polyamines spermidine and spermine are present. The DNA G $+\mathrm{C}$ content of the type strain is $68 \mathrm{~mol} \%$.

The type strain, $\mathrm{UI}^{\mathrm{T}}\left(=\mathrm{CCM} 7428^{\mathrm{T}}=\right.$ MTCC $\left.8591^{\mathrm{T}}\right)$, was isolated from $\mathrm{HCH}$-contaminated soil at Ummari village, Lucknow, India.

\section{Acknowledgements}

This research was supported by funds from Department of Biotechnology (DBT) and National Bureau of Agriculturally Important Microorganisms (NBAIM), Government of India. P.S., M. V., K. B. and A. N. gratefully acknowledge the Council of Scientific and Industrial Research (CSIR) and DBT for providing research fellowships and SAIF-DST, Department of Anatomy, AIIMS for providing the TEM facility. The authors also thank M. Dadhwal and S. K. Gupta for work on the HCH dump site and polar lipid profiling, respectively.

\section{References}

Arden Jones, M. P., McCarthy, A. J. \& Cross, T. (1979). Taxonomic and serological studies on Micropolyspora faeni and Micropolyspora strains from soil bearing the specific epithet rectivirgula. J Gen Microbiol 115, 343-344.

Brosius, J., Palmer, M. L., Kennedy, P. J. \& Noller, H. F. (1978), Complete nucleotide sequence of a $16 \mathrm{~S}$ ribosomal RNA gene from Escherichia coli. Proc Natl Acad Sci U S A 75, 4801-4805.

Busse, J. \& Auling, G. (1988). Polyamine pattern as a chemotaxonomic marker within the Proteobacteria. Syst Appl Microbiol 11, 1-8.

Busse, H.-J., Bunka, S., Hensel, A. \& Lubitz, W. (1997). Discrimination of members of the family Pasteurellaceae based on polyamine patterns. Int J Syst Bacteriol 47, 698-708.

Christensen, W. B. (1946). Urea decomposition as a means of differentiating Proteus and paracolon cultures from each other and from Salmonella and Shigella types. J Bacteriol 52, 461-466.

Collins, M. D., Pirouz, T., Goodfellow, M. \& Minnikin, D. E. (1977). Distribution of menaquinones in actinomycetes and corynebacteria. J Gen Microbiol 100, 221-230.

Cowan, S. T. \& Steel, K. J. (1965). Manual for the Identification of Medical Bacteria. London: Cambridge University Press.

Dadhwal, M., Singh, A., Prakash, O., Gupta, S. K., Kumari, K., Sharma, P., Jit, S., Verma, M., Holliger, C. \& Lal, R. (2009). Proposal of biostimulation for hexachlorocyclohexane $(\mathrm{HCH})$-decontamination and characterization of cultural bacterial community from high-dose point HCH-contaminated soils. J Appl Microbiol 106, 381-392.

Farmer, J. J., III (1999). Enterobacteriaceae: introduction and identification. In Manual of Clinical Microbiology, 7th edn, pp. 448-452. Edited by P. R. Murray, E. J. Baron, M. A. Pfaller, F. C. Tenover \& R. H. Yolken. Washington, DC: American Society for Microbiology.

Felsenstein, J. (1993). PHYLIP (phylogeny inference package) version 3.5c. Distributed by the author. Department of Genome Sciences, University of Washington, Seattle, USA.
Godoy, F., Vancanneyt, M., Martínez, M., Steinbüchel, A., Swings, J. \& Rehm, B. H. A. (2003). Sphingopyxis chilensis sp. nov., a chlorophenol-degrading bacterium that accumulates polyhydroxyalkanoate, and transfer of Sphingomonas alaskensis to Sphingopyxis alaskensis comb. nov. Int J Syst Evol Microbiol 53, 473-477.

Gonzalez, J. M. \& Saiz-Jimenez, C. (2002). A fluorimetric method for the estimation of $\mathrm{G}+\mathrm{C}$ mol\% content in microorganisms by thermal denaturation temperature. Environ Microbiol 4, 770-773.

Gordon, R. E., Barnett, D. A., Handerhan, J. E. \& Pang, C. H.-N. (1974). Nocardia coeliaca, Nocardia autotrophica, and the nocardin strain. Int J Syst Bacteriol 24, 54-63.

Gupta, S. K., Lal, D. \& Lal, R. (2009). Novosphingobium panipatense sp. nov. and Novosphingobium mathurense sp. nov., from oil-contaminated soil. Int J Syst Evol Microbiol 59, 156-161.

Jit, S., Dhadwal, M., Prakash, O. \& Lal, R. (2008). Flavobacterium lindanitolerans sp. nov., isolated from hexachlorocyclohexanecontaminated soil. Int J Syst Evol Microbiol 58, 1665-1669.

Jukes, T. \& Cantor, C. R. (1969). Evolution of protein molecules. In Mammalian Protein Metabolism, vol. 3, pp. 21-132. Edited by H. N. Munro. New York: Academic Press.

Kämpfer, P., Witzenberger, R., Denner, E. B. M., Busse, H.-J. \& Neef, A. (2002). Sphingopyxis witflariensis sp. nov., isolated from activated sludge. Int J Syst Evol Microbiol 52, 2029-2034.

Kim, M. K., Im, W.-T., Ohta, H., Lee, M. \& Lee, S.-T. (2005). Sphingopyxis granuli sp. nov., a $\beta$-glucosidase-producing bacteria in the family Sphingomonadaceae in $\alpha-4$ subclass of the Proteobacteria. J Microbiol 43, 152-157.

Kim, B. S., Lim, Y. W. \& Chun, J. (2008). Sphingopyxis marina sp. nov. and Sphingopyxis litoris sp. nov., isolated from seawater. Int J Syst Evol Microbiol 58, 2415-2419.

Kumar, M., Verma, M. \& Lal, R. (2008). Devosia chinhatensis sp. nov., isolated from a hexachlorocyclohexane $(\mathrm{HCH})$ dump site in India. Int J Syst Evol Microbiol 58, 861-865.

Kumari, R., Subudhi, S., Suar, M., Dhingra, G., Raina, V., Dogra, C., Lal, S., van der Meer, J. R., Holliger, C. \& Lal, R. (2002). Cloning and characterization of $l i n$ genes responsible for the degradation of hexachlorocyclohexane isomers by Sphingomonas paucimobilis strain B90. Appl Environ Microbiol 68, 6021-6028.

Lee, J.-S., Shin, Y. K., Yoon, J.-H., Takeuchi, M., Pyun, Y.-R. \& Park, Y.-H. (2001). Sphingomonas aquatilis sp. nov., Sphingomonas koreensis sp. nov. and Sphingomonas taejonensis sp. nov., yellow-pigmented bacteria isolated from natural mineral water. Int J Syst Evol Microbiol 51, 1491-1498.

Lee, M., Ten, L. N., Lee, H.-W., Oh, H. W., Im, W.-T. \& Lee, S.-T. (2008). Sphingopyxis ginsengisoli sp. nov., isolated from soil of a ginseng field in South Korea. Int J Syst Evol Microbiol 58, 2342-2347.

McCarthy, A. J. \& Cross, T. (1984). A taxonomic study of Thermomonospora and other monosporic actinomycetes. J Gen Microbiol 130, 5-25.

Pal, R., Bhasin, V. K. \& Lal, R. (2006). Proposal to reclassify [Sphingomonas] xenophaga Stolz et al. 2000 and [Sphingomonas] taejonensis Lee et al. 2001 as Sphingobium xenophagum comb. nov. and Sphingopyxis taejonensis comb. nov., respectively. Int J Syst Evol Microbiol 56, 667-670.

Prakash, O., Kumari, K. \& Lal, R. (2007a). Pseudomonas delhiensis sp. nov., from a fly ash dumping site of a thermal power plant. Int J Syst Evol Microbiol 57, 527-531.

Prakash, O., Verma, M., Sharma, P., Kumar, M., Kumari, K., Singh, A., Kumari, H., Jit, S., Gupta, S. \& other authors (2007b). Polyphasic approach of bacterial classification - an overview of recent advances. Indian J Microbiol 47, 98-108. 
Saitou, N. \& Nei, M. (1987). The neighbor-joining method: a new method for reconstructing phylogenetic trees. Mol Biol Evol 4, 406425.

Stackebrandt, E. \& Goebel, B. M. (1994). Taxonomic note: a place for DNA-DNA reassociation and $16 \mathrm{~S}$ rRNA sequence analysis in the present species definition in bacteriology. Int J Syst Bacteriol 44, 846-849.

Takeuchi, M., Kawai, F., Shimada, Y. \& Yokota, A. (1993). Taxonomic study of polyethylene glycol-utilizing bacteria: emended description of the genus Sphingomonas and new descriptions of Sphingomonas macrogoltabidus sp. nov., Sphingomonas sanguis sp. nov., and Sphingomonas terrae sp. nov. Syst Appl Microbiol 16, 227-238.

Takeuchi, M., Hamana, K. \& Hiraishi, A. (2001). Proposal of the genus Sphingomonas sensu stricto and three new genera, Sphingobium, Novosphingobium and Sphingopyxis, on the basis of phylogenetic and chemotaxonomic analysis. Int J Syst Evol Microbiol 51, 1405-1417.

Thompson, J. D., Gibson, T. J., Plewniak, F., Jeanmougin, F. \& Higgins, D. G. (1997). The CLUSTAL_X windows interface: flexible strategies for multiple sequence alignment aided by quality analysis tools. Nucleic Acids Res 25, 4876-4882.

Tourova, T. P. \& Antonov, A. S. (1988). Identification of microorganisms by rapid DNA-DNA hybridization. Methods Microbiol 19, 333355.

Van de Peer, Y. \& De Wachter, Y. (1994). TREECON for Windows: a software package for the construction and drawing of evolutionary trees for the Microsoft Windows environment. Comput Appl Biosci 10, 569-570.

Vanbroekhoven, K., Ryngaert, A., Bastiaens, L., Wattiau, P., Vancanneyt, M., Swings, J., Mot, R. D. \& Springael, D. (2004). Streptomycin as a selective agent to facilitate recovery and isolation of introduced and indigenous sphingomonads from environmental samples. Environ Microbiol 6, 1123-1136.

Vancanneyt, M., Schut, F., Snauwaert, C., Goris, J., Swings, J. \& Gottschal, J. C. (2001). Sphingomonas alaskensis sp. nov., a dominant bacterium from a marine oligotrophic environment. Int J Syst Evol Microbiol 51, 73-79.

Wayne, L. G., Brenner, D. J., Colwell, R. R., Grimont, P. A. D., Kandler, O., Krichevsky, M. I., Moore, L. H., Moore, W. E. C., Murray, R. G. E. \& other authors (1987). International Committee on Systematic Bacteriology. Report of the ad hoc committee on reconciliation of approaches to bacterial systematics. Int J Syst Bacteriol 37, 463464.

Yoon, J.-H. \& Oh, T.-K. (2005). Sphingopyxis flavimaris sp. nov., isolated from sea water of the Yellow Sea in Korea. Int J Syst Evol Microbiol 55, 369-373.

Yoon, J.-H., Lee, C.-H., Yeo, S.-H. \& Oh, T.-K. (2005). Sphingopyxis baekryungensis sp. nov., an orange-pigmented bacterium isolated from sea water of the Yellow Sea in Korea. Int J Syst Evol Microbiol 55, 1223-1227. 